\title{
Effect of Brewer's yeast and soya bean cake on brood rearing, pollen gathering and honey yield in honey bee colonies.
}

\author{
Naglaa E. Ghazala ${ }^{1}$ and E.E, Nowar ${ }^{2}$ \\ ${ }^{1}$ Plant Protection Res. Inst., Agric. Res. Center, Dept. of bees Research, Qanater. \\ ${ }^{2}$ Plant protection department, Fac. Agric., Moshtohor, Benha University
}

\begin{abstract}
This work was conducted in the Apiary of Plant Protection Institute at Quantar, Qaluobia to study the effect of additive pollen substitute feeding of honey bee colonies on brood rearing, queen's egg laying, pollen gathering and honey production through the period of $1 / 3 / 2012$ to $29 / 08 / 2012$. Results revealed that feeding the honey bee colonies on additive pollen substitute and sugar syrup (1:1) make honey bee colonies have significantly more brood rearing, queen's egg laying, pollen gathering and honey production than the control colonies which fed with sugar syrup only.
\end{abstract}

Key Words: Honey bees; pollen; honey, brood rearing soya bean cake, Brewer's yeast.

\section{Introduction}

Testing and utilization of different materials as pollen supplements have been mainly directed toward producing brood, and less attention has been given to the pollen gathering and honey production during spring and summer seasons of the year. The pollen is more attractive to bees than the other proteins (ElBanby and Gorgui, 1970). Various types of Brewer's yeast have found extensive application in pollen substitute formulations (Johanson and Johanson, 1977 and Herbert et al., 1978); Its candy type-proved the most efficient method (Doul, 1975b and El-Banby and El-Sherif, 1987a,b) especially for worker production and longevity. Sucrose syrup 66.6 or $50 \%$ gave the best results for worker and drone production and longevity (El-Sherif and El-Banby, 1989; ElSherif et al. 1994). The brood area of honey bee (Apis mellifera) colonies fed weekly with 2 liters of sugar syrup fortified with isolecucine significantly increased more than in colonies fed sugar syrup only, when colonies were located in an area with adequate pollen sources, but did not do so in an area with poor pollen supplies. It also increased acceptance of grafted queen cells and cell production per colony, and decreased consumption of supplementary food (Stace and White, 1994). The supplementary feeding on sunflower flour, agwa, or Yeast significantly increase brood area compared to feeding on sugar syrup only. There was no obvious consistent preference between the three tested diets since the results varied with season (Mishref $\boldsymbol{e t}$ al., 1995). The amount of stored pollen and brood rearing area in strong colonies were higher for all seasons than in weak colonies. The lowest amounts of stored pollen in both strong and weak colonies were recorded in winter, while the lowest brood activity was recorded in autumn. High correlation coefficients were found between worker brood and stored pollen in both strong and weak colonies (Fathy, 1998). Feeding honey bee colonies on sugar syrup fortified with a vitamin-mineral preparation (Forssatom) or brewer's yeast during spring and autumn indicated that the greatest brood area in the spring was recorded in the group fed on sugar syrup fortified with the vitaminmineral preparation (6.8\% increase when compared to the control group). The greatest brood area in the autumn was observed in the group fed syrup fortified with yeast (25.4\% increase than in the control group). In the spring the greatest honey area was recorded in the group fed on syrup fortified with yeast $(37.8 \%$ higher than the control). In the autumn the highest values were obtained in the group fed on sugar syrup fortified with the vitamin-mineral preparation (181.7\% higher than in the control hives) (Mladenovic et al., 1999). Studying the effect of pollen or pollen substitutes on workers broods rearing. The used materials were :wheat germ, yeast, soybean, mung bean, mung bean and Sativa vulgaris. The obtained results revealed that the worker brood areas in colonies fed with used materials had extended over greater areas than in the case of unfed ones where the colonies fed with mung bean, wheat germ, soybean, yeast, and Sativa vulgaris showed worker broad areas of 31-66, 27.96, 20.21, 15.48 and $1.56 \%$ more than the control ones (EL-Shaarawi , 2001) The honey bee colonies provided with pollen substitutes of bran, yeast and check pea reared more worker brood than in case on unfed ones (control colonies). (EL-Waseef, 2002). As the winter progresses sweet pepper flowers produce fewer pollen grains and with reduced viability, and thus greater pollinator activity is needed. By feeding pollen supplements (500 g/week), colonies maintained in enclosures of sweet pepper over the long flowering period of the crop, could sustain stable levels of brood 
production, which are needed for achieving efficient pollination (Kalev et al., 2002). Feeding honey bee colonies with pollen substitutes plus sugar syrup significantly increased the sealed brood area and egg laying rates of Queens than control colonies which were fed on plain sugar syrup (1:1) (Ghazala, 2006). This work was conducted to study the effect of pollen substitute as a source of proteins beside sugar syrup during dearth periods in the activity season from $1 / 3$ to $29 / 8 / 2012$ on brood rearing, queen's egg laying rate, pollen collection and honey production in Quantar region, Qaluobia governorate.

\section{Materials and Methods}

The experiment was carried out under the Apiary conditions at the Institute of Plant Protection in Quantar, Qaluobia governorate during the period of 1/3 to $29 / 08 / 2012$. Six honeybee colonies headed with F1 Carniolan open-mated queens, were selected. They were equal in their population density, brood rearing area, honey and pollen stores. They were divided into two groups; each consisted of 3 colonies (replicates). Each group of colonies was offered one of the following feeding treatments at 7 days intervals

- Treatment (A): Each colony received $100 \mathrm{~g}$ of pollen substitute (consisting of $20 \%$ dried Brewer yeast + $40 \%$ Soybean flour $+40 \%$ sugar mixed with honey) beside 1000 cc sugar syrup (50\%). Soybean flour and dried Brewer yeast contain $50.88 \%$ and $40.5 \%$ protein respectively according to Atallah, (1975) and Hammad, (2000).

- Treatment (B): Each colony received $1000 \mathrm{cc}$ plain sugar syrup only (50\%), as a control.

Worker sealed brood areas were measured with a standard frame divided to before the beginning of the experiment on $1_{\text {st }}$ March, and extende to $29 / 8 / 2012$.

To calculate the daily number of egg laying at 12 day intervals, the following equation was used according to Ghazala, (2006):

Daily rate of egg laying $=$

Brood area (inches) x 25 (number of workers of cells per inches)

\section{2 days}

\section{- Pollen gathering activity:}

A pollen Trap was placed at the hive entrance of each experimental colony. Traps used were similar to those used by Kaulfeled (1973), Bobrzecki and Wilde (1991), Cornejo (1991), Wilde et al., (1994). This experiment started from the $1^{\text {st }}$ March, 2012 and ended at the end of August, 2012. The Traps were fitted to the colonies 3 days only and removed to collect the pollen, then the bees enter the colonies free at the following 3 days and the traps were fitted again, respectively the trapped pollen was dried at $40 \mathrm{C}^{\circ}$ in air dried (Oven TEQ model ST-50 v), package in nylon (plastic) bags and stored at $-5 \mathrm{C}^{\circ}$ freezing. The weight of dried pollen was recorded.

\section{- Honey production:-}

The honey yield (Clover season) from tested colonies was estimated in $\mathrm{kg} /$ colony.

\section{Statistical analysis:}

T- test and M. static computer analysis program were conducted according to Sendecor and Coehran, 1973.

\section{Results and discussion}

\section{1- Brood rearing:}

Data in Table (1) and Fig. (1), show that no significant difference observed between the mean values of sealed brood area in the two tested groups of honey bee colonies at the begining of the expermintal. The colonies fed with pollen supplements beside sugar syrup produced more brood area Than those fed on plain sugar syrup.

Data show that the general mean of brood area/colony/ 12 days intrvals in treated colonies which fed on sugar syrup fortified with pollen substitute was significantly higher the control. Pollen substitute gave the highest area of sealed brood ( $654.93 \mathrm{inch}^{2} /$ colony/ 12 days) inrevals while control gave the lowest area during period of study( $287.98 \mathrm{inch}^{2}$ /colony/ 12 days) inrevals. Results obtained were in agremment with Atalla 1975; Shoreit and Hussein 1993; Hammad 2000; Nabors 2000; EL- Bassiouny 2006; Mattila and Otis 2006 and Ashour et al., 2008

Data in Table (2) and Fig.(2) reflected that the general means of queens egg laying/colony in colonies fed on sugar syrup fortified with pollen substitute were significantly increase than control which were fed on sugar syrup $(1: 1)$ only. The pollen substitute gave the highest queens egg laying rate (1321.74 egg/colony/day), while control gave the lowest queens egg laying late during study period 606.37 egg/colony/day. 
Table 1. Effect of feeding pollen substitute on the mean sealed brood area $\left(\right.$ inch $\left.^{2}\right)$ during 2012.

\begin{tabular}{|c|c|c|}
\hline $\begin{array}{ll}\text { Date of inspection } & \text { Diet }\end{array}$ & $\begin{array}{c}\text { Pollen supplement beside } \\
\text { sugar syrup }\end{array}$ & $\begin{array}{c}\text { Control } \\
\text { (plain sugar syrup) }\end{array}$ \\
\hline $1 / 3$ & 145.50 & 146.53 \\
\hline $13 / 3$ & 255.17 & 150.10 \\
\hline $25 / 3$ & 309.87 & 160.73 \\
\hline $6 / 4$ & 323.27 & 164.70 \\
\hline $18 / 4$ & 376.87 & 170.00 \\
\hline $30 / 4$ & 419.97 & 183.13 \\
\hline $12 / 5$ & 490.60 & 198.70 \\
\hline $24 / 5$ & 535.20 & 228.80 \\
\hline $5 / 6$ & 598.90 & 265.90 \\
\hline $17 / 6$ & 741.10 & 358.57 \\
\hline $29 / 6$ & 820.30 & 379.50 \\
\hline $11 / 7$ & 1051.90 & 398.97 \\
\hline $23 / 7$ & 1079.40 & 419.87 \\
\hline $5 / 8$ & 1092.67 & 452.60 \\
\hline $17 / 8$ & 1112.30 & 446.47 \\
\hline $29 / 8$ & 1125.80 & 483.10 \\
\hline Mean & 654.93 & 287.98 \\
\hline
\end{tabular}

T stat $=6.51$

T table at 5\% $=2.1$

at $1 \%=\mathbf{1 . 7 5}$

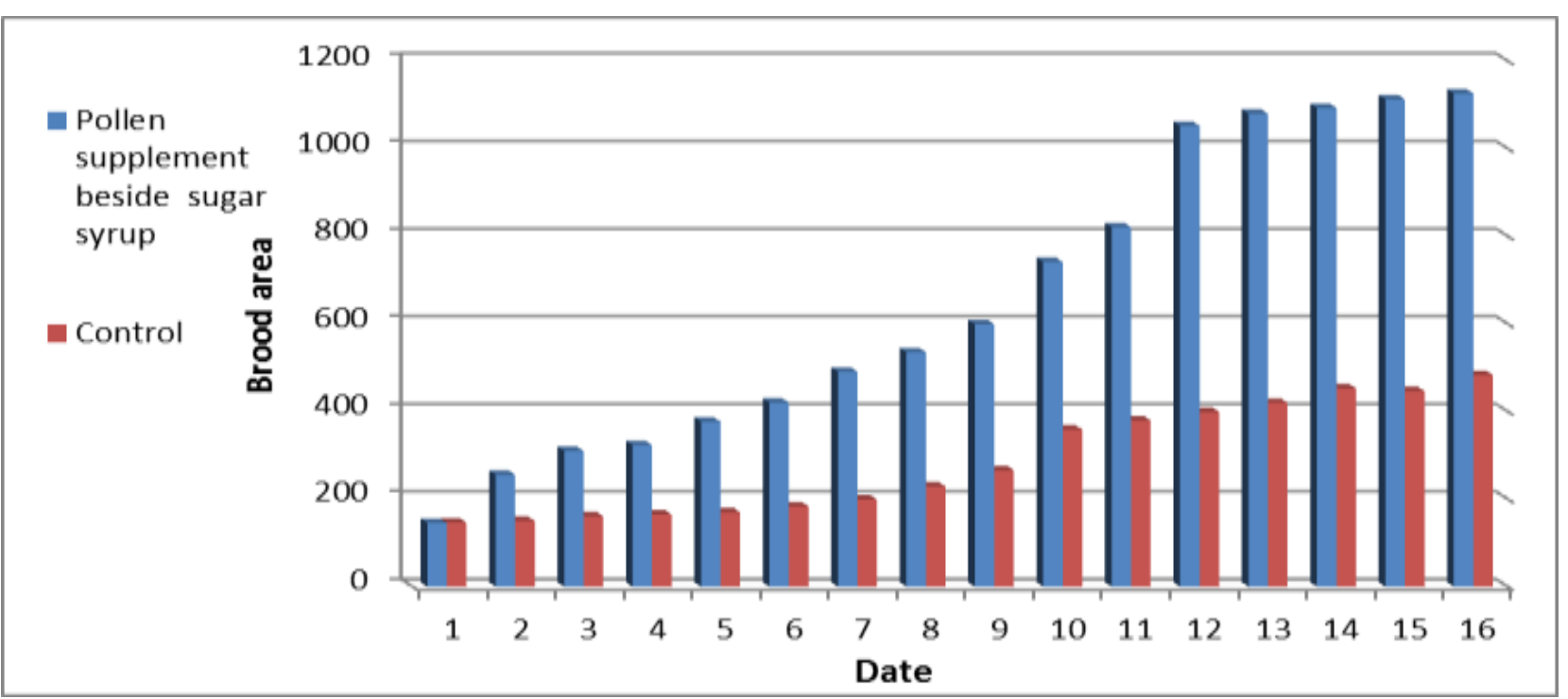

Fig.(1): Effect of feeding pollen substitute on the mean sealed brood area (inch $\left.{ }^{2}\right)$ during 2012. 
Table 2. Effect of feeding pollen substitute on the mean of daily queen's egg laid in the dates of inspection in the colonies during 2012.

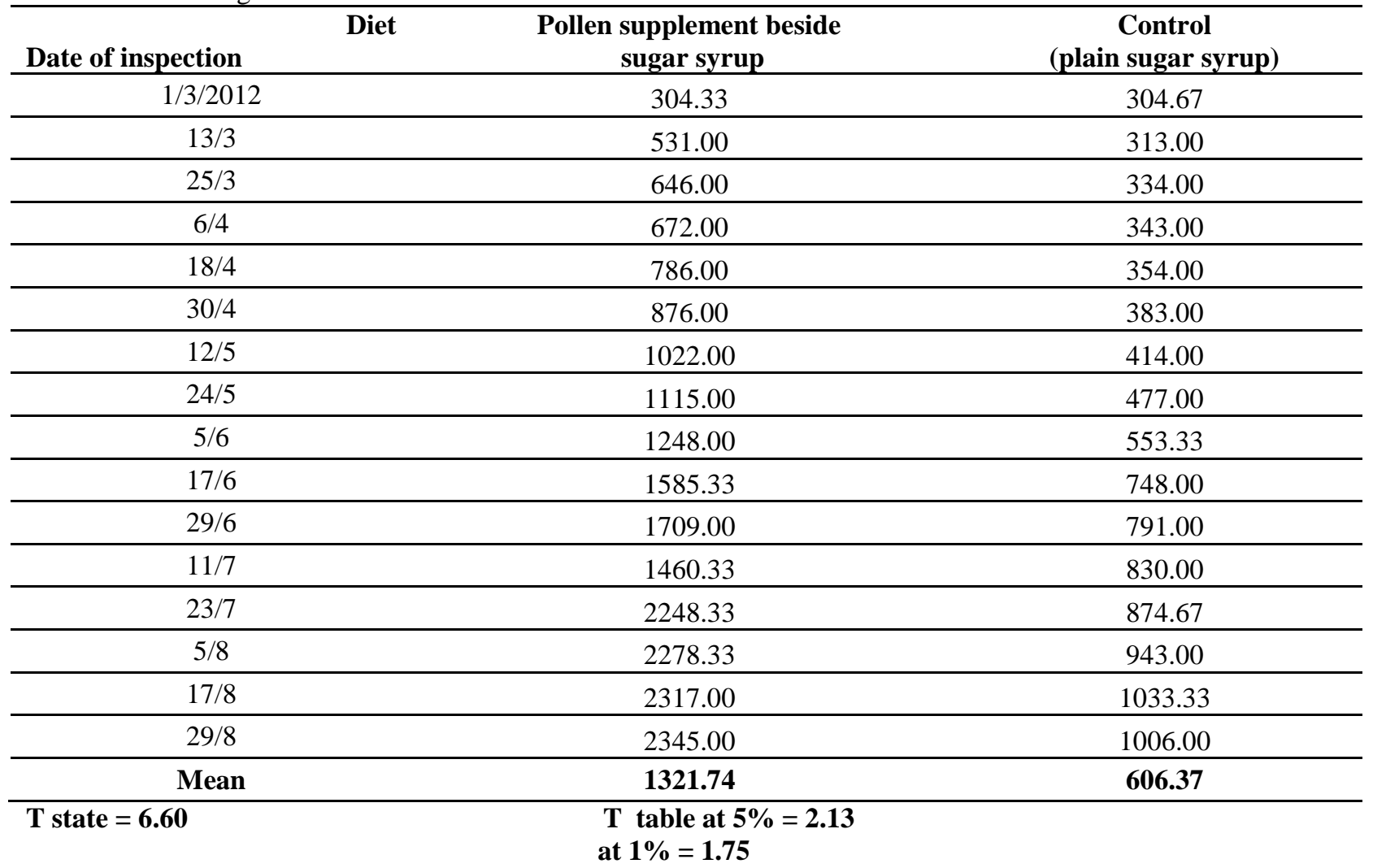

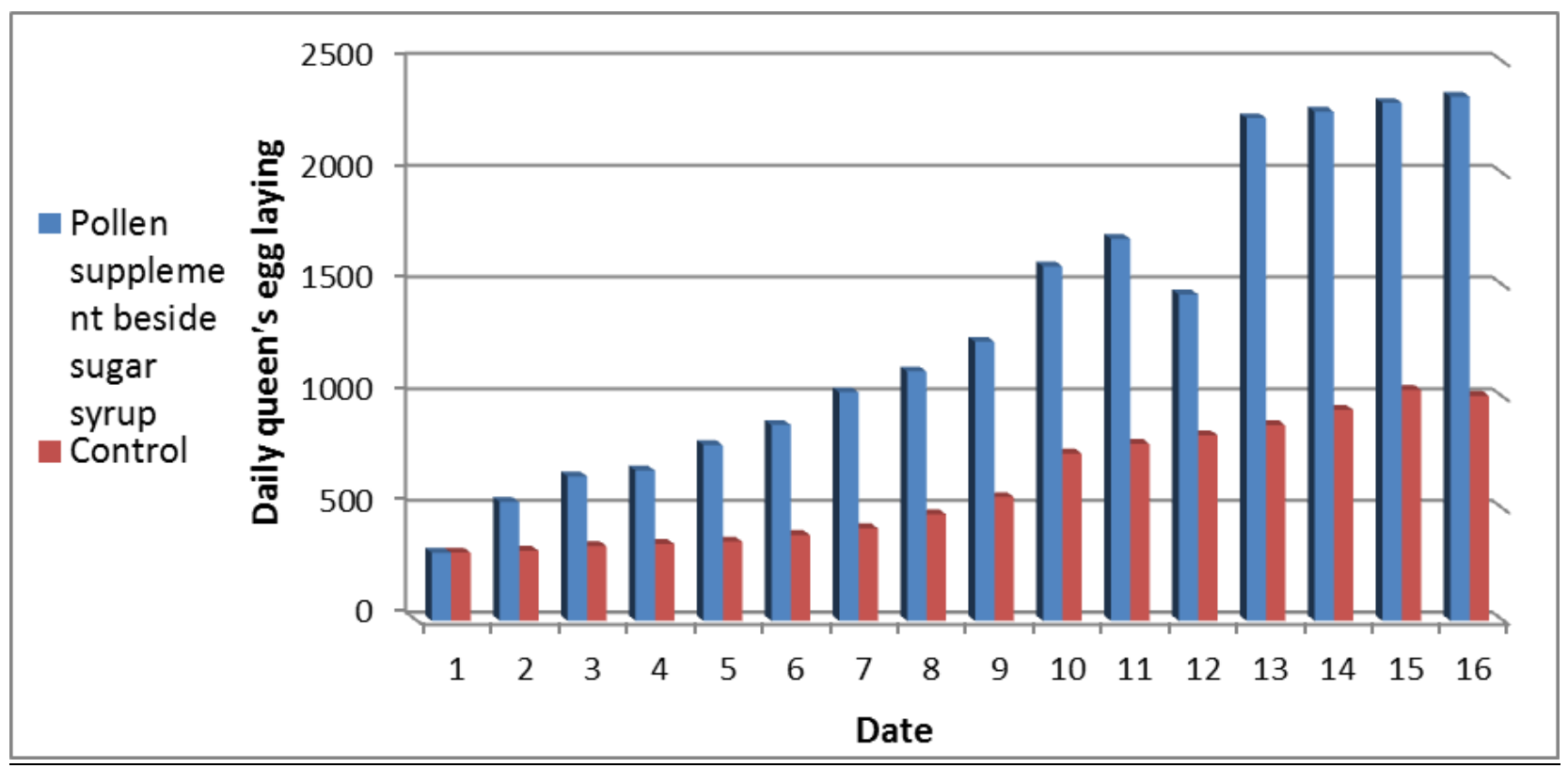

Fig. 2 Effect of feeding pollen substitute on the mean of daily queen's egg laid in the dates of inspection in the colonies during 2012. 


\section{2- Collocation of pollen:}

Data in Table (3) and Fig.(3) shows that, the colony feeding with pollen substitute beside sugar syrup significantly increased the collected amounts of pollen at the different months during 2012 with an average of $603.78 \mathrm{~g} /$ colony compared with the colony feeding pollen plain sugar syrup ( $456.32 \mathrm{~g} /$ colony).

In August during period of study The pollen substitute significantly gave the highest mean amount of pollen (797.9 g/colony), while control gave (691.10 g. /colony).

Table 3. Effect of feeding pollen substitute on the mean pollen yield (g. /colony) during some months of 2012.

\begin{tabular}{|c|c|c|c|c|c|c|}
\hline \multicolumn{2}{|c|}{$\begin{array}{l}\text { Diets } \\
\text { Months }\end{array}$} & \multicolumn{2}{|c|}{$\begin{array}{l}\text { Pollen supplement beside } \\
\text { sugar syrup }\end{array}$} & \multicolumn{2}{|c|}{$\begin{array}{c}\text { Control } \\
\text { (plain sugar syrup) }\end{array}$} & Means \\
\hline March & \multirow{3}{*}{ Spring } & 337.4 & \multirow{3}{*}{1278.5} & 297.1 & \multirow{3}{*}{987.7} & 317.3 \\
\hline April & & 450.2 & & 330.1 & & 390.1 \\
\hline May & & 490.9 & & 360.5 & & 425.7 \\
\hline June & \multirow{3}{*}{ Summer } & 755.7 & \multirow{3}{*}{2344.2} & 480.7 & \multirow{3}{*}{1750.2} & 618.2 \\
\hline July & & 790.6 & & 578.4 & & 684.5 \\
\hline August & & 797.9 & & 691.1 & & 744.5 \\
\hline Mean & & \multicolumn{2}{|c|}{603.78} & \multicolumn{2}{|c|}{456.32} & 3180.3 \\
\hline
\end{tabular}

T state $=\mathbf{4 . 3 4}$

T table at $5 \%=2.57$

at $1 \%=2.01$

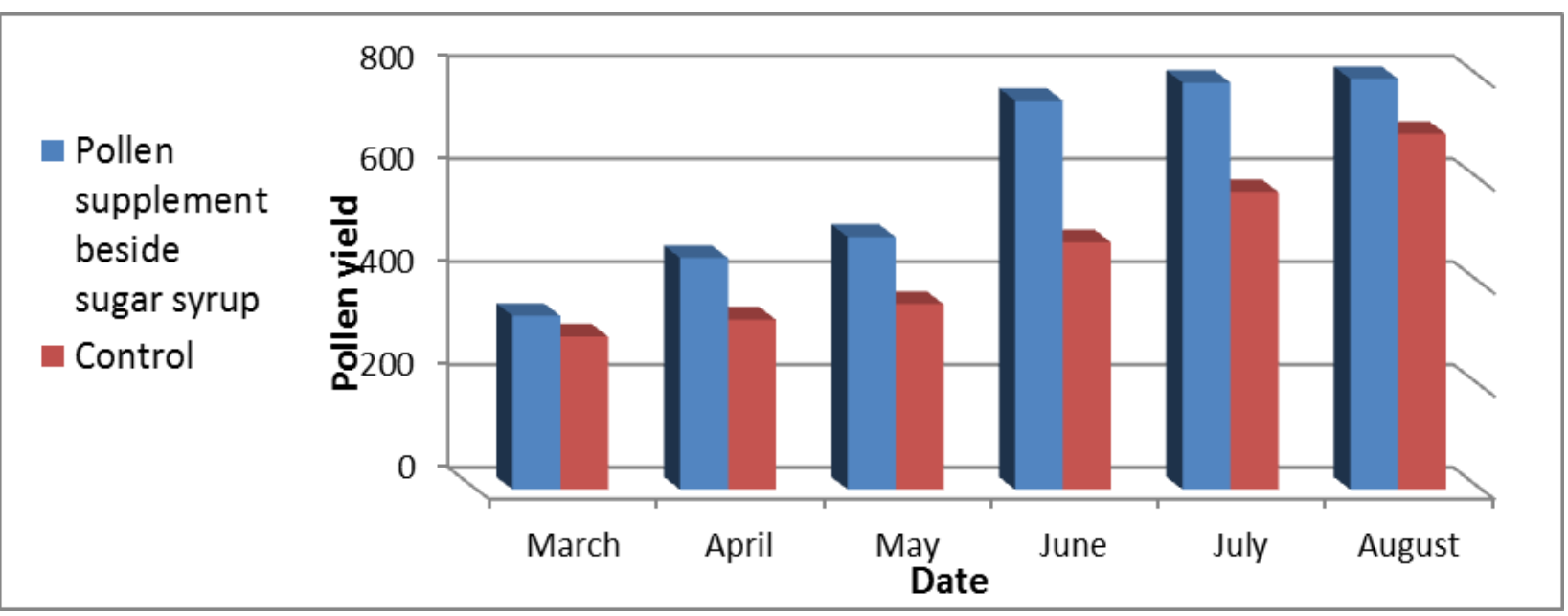

Fig. (3): Effect of feeding pollen substitute on the mean pollen yield (g./colony) during some months of 2012.

The colony feeding with pollen supplements beside sugar syrup significantly increase the amount of collected pollen in spring and summer seasons during 2012 and averaged 1278.5 and 2344.2 g/colony, respectively, compared to the feeding on plain sugar syrup as they averaged 987.7 and 1750.2 g/colony respectively. The largest collected amounts of pollen were occurred during the summer season in both groups of colonies fed on sugar syrup fortified with pollen substitute or on plain sugar syrup and averaged 2048.71 and $1133.09 \mathrm{~g} /$ colony respectively.

\section{3-Honey production in $\mathrm{kg} /$ colony.}

Table (4) indicated that the honey bee colonies which fed with pollen substitute beside sugar syrup produced significantly more Clover honey yield as compared with control which fed on sugar syrup only and averaged 10.20 and $7.60 \mathrm{~kg} /$ colony, respectively.

Table 4. Effect of the pollen substitute on Clover honey yield in kg./colony at Quantar during 2012 season.

\begin{tabular}{ll}
\hline Diets & $\begin{array}{l}\text { Honey production in } \\
\text { kg/colony }\end{array}$ \\
\hline Pollen substitute & $\mathbf{1 0 . 2 0}$ \\
\hline Control & $\mathbf{7 . 6 0}$ \\
\hline
\end{tabular}

Results obtained were in agreement with Hussein (1979) and Shoreit and Hussein (1993), 


\section{Conclusion}

It can be concluded that feeding colonies with pollen substitute cake beside sugar syrup during spring and summer seasons stimulates of queens to lay more eggs and encourages workers to rear more brood. This significant increase in brood rearing reflects a significant increase the colony population and pollen and honey production.

\section{References}

Ashour, A. T.; Zakaria, M. E.; Hammad, H. M. and Nour, M. E. (2008). Effects of some diets as pollen substitutes on certain biological activities of honeybee colonies. Bulletin of Faculty of Agriculture, Cairo University, Faculty of Agriculture, Cairo University 59: 2, 96-102.

Atallah, M. A. (1975). Studies on the effect of different carbohydrate and protein

Bobrzecki, J. And Wilde, J. (1991). The influence of pollen trapping by 3 types of pollen traps on the development and productivity of honey bee colonies . Pszczelnicze Zesz. Naukowe, 35, 19-27.

Cornejo, L. G. (1991). Industrial production of pollen. Industria Aptcola, 1:12-23. diets on honey bee colonies. PhD. Thesis, Fac. of Agric., Cairo Univ. diets on honey bee colonies. PhD. Thesis, Fac. of Agric., Cairo Univ.

Doul,K.M. (1975b) Pollen supplements. II. Making effective use of supplementaryEL-Shaarawi, M. O. (2001). The effect of feeding honeybee colonies by pollen substitutes on worker brood rearing and citrus honey. J. Agric. Sci. Mansoura Univ., 26 (6): 3983-3987. feeding. Amer. Bee J.,115(3): 88-89 and 99.

El-Waseef, ,R. A. (2002). Ecological and physiological studies on honeybee colonies underdifferrent environmental conditions . M. Sc. Thesis, Fac. Of Agric., Cairo Univ.

El -Bassiouny, A. M. (2006). Effect of vitamin additive and colony management on honey bee performance. Arab Universities Journal of Agricultural Sciences. Faculty of Agriculture, Ain Shams University. 14: 1, 427-438.

El-Banby, M.A. and Gorgui, W.A.(1970) Development of honey bees whose colonies are fed on sugar syrup and different kinds of pollen substitutes. Res. Bull. 610: 1-22, Fac. Agric., Ain Shams Univ., Shobra-Kheima, Cairo, Egypt.

El-Banby,M.A. and M.E. El-Sherif, (1987a) Effect of brewer's yeast and supramine cakes on brood rearing and worker bees longevities. $2^{\text {nd }}$ Nat. Conf. of Pests \& Dis of Veg. \& Fruits, Ismailia: 594-605.

El-Banby,M.A. and M.E. El-Sherif, (1987b) Comparison between brewer's yeast and fortified maize and sorghum flours as pollen substitutes. $2^{\text {nd }}$
Nat. Conf. of Pests \& Dis of Veg. \& Fruits, Ismailia: 606-613.

El-Sherif M.E. and M.A. El-Banby (1989) Effect of honey combs and sugar feed on the build-up of honeybee colonies. $7^{\text {th }}$ Arab Pesticide Conf., Tanta Univ., 99-106.

El-Sherif, M.E.; M.A. El-Banby and H.T. Abou ElEnain (1994) Effect of diet regimes on drone production longevity and maturity. 5th Conf. Agric. Dev. Res. Fac. Agric. Ain Shams Univ. Cairo, Egypt, 2:655-669.

Fathy,H.M (1998). Seasonal variations in brood rearing activity and stored pollen according to colony strength. J.Agric.Sci. Mansoura Univ.,23:6231-6237.

Ghazala, Naglaa, E. (2006). Propolis and pollen as products of honeybee colonies and their biological properties. Ph.D. Agricultural Science of Economic Entomology, Faculty of Agriculture Shiben ElKom, Menoufiya University, 206 pp.

Hammad, A. A. (2000). Chemical and technological studies on soybean proteins. Ph.D. Thesis, Fac. of Agric., Moshtohor, Zagazig Univ.

Herbert et, E.W. and Shimanuki, H.(1978) Consumption and brood rearing by caged honey bees fed pollen substitutes fortified with various sugars. J.Apic.Rec.17 (1): 27-31.

Johanson, T.S.K. and Johanson,M.P. (1977) Feeding honey bees pollen and pollen substitutes. Bee Wld. 58: 105-118, 135, 161-164.

Kalev, H., A. Dag, and S. Shafir.(2002) Feeding pollen supplements to honey bee colonies during pollination of sweet peppers in enclosures. Am. Bee J 2002. 142:675-679.

Kaulfeld, N. M. (1973). Pollen trap with trash collector. Amer. Bee, J.; 113 (11)

Mattila, H. R. and Otis, G. W. (2006). Influence of pollen diet in spring on development of honey bee (Hymenoptera: Apidae) colonies. Journal of Univ. Economic

Mishref, A. E.; hanna, M. A.; ghoniemy, H. A. and Owayss, Aaa. A. (1995). The effect of supplementary feeding on the production of worker brood, honey and royal jelly. Faculty of Agric., Fayoum, Cairo Univ. Egypt. (unpublished).99: 3, 604-613.

Mladenovic, M., Mlaan, V. and Dugalic Vrndic, N (1999). Effects of a vitamin-mineral preparation on development and productivity of bee colonies. Acta Veterinaria (Beograd). 1999. 49: 177-184.

Nabors, R. (2000). The effects of spring feeding pollen substitute to colonies of Apis mellifera. American Bee Journal 140: 4, 322-323.

Snedecor, G.W-and G.Cochran (1973). statistical methods $6^{\text {th }}$ ed .Lousa state Univ. Press Iowa USA.560ppStace, P. and E. White. (1994) . The 
use of isoleucine as a supplement feed for honey bees (Apis mellifera in

Australia. Australasian Beekeeper, 96: 164-166.

Shoriet, M. N. and Hussein, M. N. (1993). Field tests with some protein supplements for feeding bees at Assuit Governorate . Egypt. J. Appl. Sci., 8: 366375.
Wilde, J.; Krukowski, R. And Bcbrzecki, J. (1994). Comparison of trapping methods for increasing the amount of collected pollen. Acta Academiae Agriculturae ac Technieae Olsteuensis, Zootecihnica, No. 39: 181-191. 
الملخص العربى

تأثثر التظذية ببديل حبوب اللقاح (فول الصويا +الخميرة الجافة) على بعض أنشطة طوائف نحل العسل. نجلاء الأحمدى غزالة - الحسينى السيا نوار

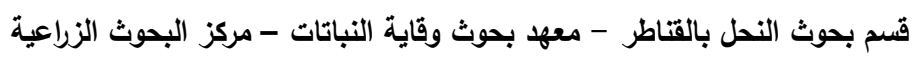

قسم وقاية النبات - كلية الزراعة - جامعة بنها

أجرى هذا البحث لدراسة تأثير استخدام بدائل حبوب اللقاح (فول الصويا + الخميرة الجافة) فى تظذية طوائف نحل العسل وتثجيعها على زيادة

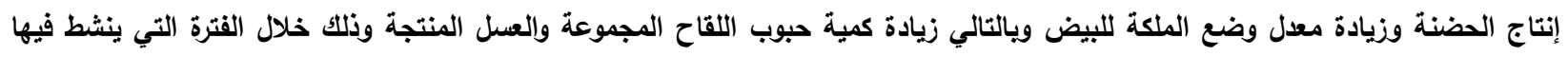
طوائف نحل العسل.

أجرى هذا البحث خلال عام 2012 فى الفترة من 2012/3/1 إلى 2012/8/29 بمحطة بحوث النحل بالقناطر الخيرية التابعة لمعهز بحوث وقاية النباتات.

وقث أثارت النتائج إلى أن الطوائف المغذاة على بائل حبوب اللقاح المضافة إلى التظذية السكرية أدت إلى فروق معنوية بالمقارنة بطوائف

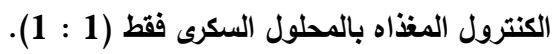

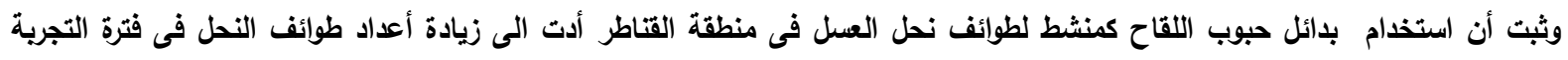

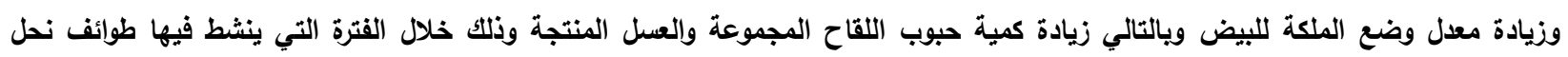
العسل.

وقد أثنارات البياتات المتحصل عليها من هذا البحث أن الطوائف التى تمت تذذيتها ببائل حبوب اللقاح أنتجت حضنه أكثر معنوية بالمقارنة

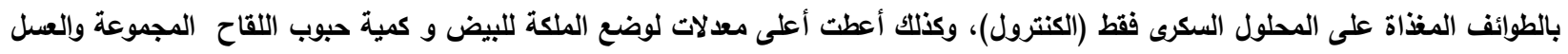
بالمقارنة بالطوائف التي تغذت على المحلول السكري فقط. 